\title{
Synthesis and characterization of naphthalimide-functionalized polynorbornenes
}

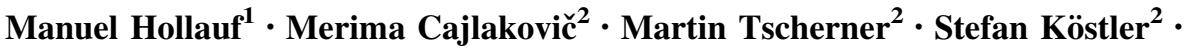 \\ Astrid-Caroline Knall ${ }^{1}$ (D) Gregor Trimmel $^{1}$
}

Received: 4 October 2016/Accepted: 29 November 2016/Published online: 21 December 2016

(c) The Author(s) 2016. This article is published with open access at Springerlink.com

\begin{abstract}
Highly fluorescent and photostable (2-alkyl)- $1 \mathrm{H}$ benzo[de]isoquinoline-1,3(2H)-diones with a polymerizable norbornene scaffold have been synthesized and polymerized using ring-opening metathesis polymerization. The monomers presented herein could be polymerized in a living fashion, using different comonomers and different monomer ratios. All obtained materials showed good film-forming properties and bright fluorescence caused by the incorporated push-pull chromophores. Additionally, one of the monomers containing a methylpiperazine functionality showed protonation-dependent photoinduced electron transfer which opens up interesting applications for logic gates and sensing.

Graphical abstract
\end{abstract}

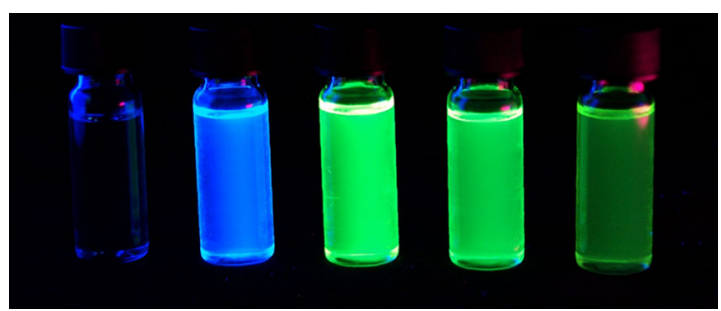

Astrid-Caroline Knall

a.knall@tugraz.at

1 ICTM-Institute for Chemistry and Technology of Materials, NAWI Graz, Graz University of Technology, Stremayrgasse 9, $8010 \mathrm{Graz}$, Austria

2 Materials, Institute for Surface Technologies and Photonics, Joanneum Research, Franz-Pichler-Straße 30, 8160 Weiz, Austria
Keywords Ring-opening metathesis polymerization · Polymerization · UV-Vis spectroscopy · Fluorescence . Dyes

\section{Introduction}

(2-Alkyl)-1 $H$-benzo[de]isoquinoline-1,3(2H)-diones (better known as 1,8-naphthalimides) are highly fluorescent and photostable compounds and are thus in the interest of various fields of technologies. For example, naphthalimides can be used as photoreactive polymerization initiators [1].

Other interesting potential applications of naphthalimide derivatives are related to organic electronics where they are especially applied in organic light emitting diodes (OLEDs) [2,3] or in organic photovoltaics (in non-fullerene acceptors and $n$-type polymers) [4].

By utilizing readily synthetically available 4-bromonaphthalic anhydride as a starting material, substituents can be straightforwardly introduced [5] yielding push-pull chromophores, whose photophysical properties strongly depend on the substituents in 6-position. These relationships, together with solvent effects and other effects (e.g., $\pi-\pi$ stacking) have been thoroughly studied [5-8].

Furthermore, chemically responsive functionalities which modulate this intramolecular charge transfer can be attached leading to functional fluorophores which can be used for sensors or imaging [9-17]. Furthermore, the photophysical properties can be further tuned by, e.g., connecting a second dye molecule in 6-position as demonstrated in chitosan-based fluorescent materials [18]. Similarly, naphthalimide-based systems were applied as fluorescent markers in molecular biology and imaging applications [19]. 
Another opportunity to modify naphthalimide-type dyes is to introduce functionalities via the imide nitrogen. This is typically utilized to tune solubility and compatibility or to attach naphthalimides to other materials [18, 20]. Alternatively, polymerizable groups can be attached to obtain functional polymers. One interesting approach is to molecularly imprint these naphthalimide-decorated materials again leading to optochemical probes [21, 22].

All of the above mentioned modification techniques can be combined, leading to photoswitchable, pH-sensitive polymers which were used to detect lysosomes in cancer cells [23].

In many applications, covalent attachment to the polymer matrix controls the distribution of the dye within the material and prevents the dye from leaching out. In particular, for biological labeling or special sensing applications, the dye molecules should be placed at a distinct location of the polymer chain, thus making a rational polymerization and labeling process necessary.

Ring-opening metathesis polymerization (ROMP) [24] has been recognized as a powerful polymerization technique due to its high functional group tolerance. Thus, a number of dye-functionalized polymers have been successfully obtained $[25,26]$, while the living nature of ROMP allowed the precise placement of dye molecules in dedicated segments of block copolymers and combining them with stimuli-responsive comonomers [27]. This renders ROMP the method of choice for the synthesis of naphthalimide-functionalized polymers which is the objective of this work. Furthermore, the photophysical properties of the obtained materials are characterized and discussed.

\section{Results and discussion}

The overall reaction scheme is depicted in Scheme 1 . Starting from 4-bromo-1,8-naphthalic anhydride, imides are prepared which are typically used for tuning the solubility of the dye or connecting the naphthalimide to a material. We use the imide functionality to link the functional naphthalimide chromophores to a norbornene residue which can be polymerized using ring-opening metathesis polymerization (ROMP). In the resulting 4-substituted 1,8-naphthalimide (formally, 6-substituted (2alkyl)-1 $H$-benzo[de]isoquinoline-1,3(2H)-dione) system, substituents are introduced in 6-position which can be varied and have a strong influence on the photophysical properties [28, 29].

Therefore, we used 4-bromo-1,8-naphthalic anhydride (1) as precursor for all synthesized naphthalimide dyes, which is then converted into 6-bromo-2-(2-hydroxyethyl)$1 H$-benzo[de]isoquinoline-1,3(2H)-dione (2), which can be straightforwardly obtained by refluxing $\mathbf{1}$ with monoethanolamine in ethanol [15].

Due to the fact that bromine is a good leaving group, 2-(2-hydroxyethyl)-6-methoxy- $1 H$-benzo[de $]$ isoquinoline1,3(2H)-dione (3) and 2-(2-hydroxyethyl)-6-(piperazin-1yl)-1H-benzo[de]isoquinoline-1,3(2H)-dione (4) could be obtained using quite mild conditions. $\mathbf{4}$ was then alkylated using paraldehyde in formic acid [30, 31] which led to 2-(2-hydroxyethyl)-6-(4-methylpiperazin-1-yl)- $1 \mathrm{H}$ -

benzo[de]isoquinoline-1,3(2H)-dione (5), see Scheme 1.

Monomers 6 (2-(6-bromo-1,3-dioxo-1H-benzo[de]isoquinolin-2(3H)-yl)ethyl bicyclo[2.2.1]hept-5-ene-2carboxylate), 7 (2-(6-methoxy-1,3-dioxo- $1 H$ benzo[de]isoquinolin-2(3H)-yl)ethyl bicyclo[2.2.1]hept-5ene-2-carboxylate), 8 (2-[1,3-dioxo-6-(piperazin-1-yl)- $1 H$ benzo[de]isoquinolin-2(3H)-yl]ethyl bicyclo[2.2.1]hept-5ene-2-carboxylate), and 9 (2-[6-(4-methylpiperazin-1-yl)1,3-dioxo-1 $H$-benzo[de]isoquinolin-2(3H)-yl]ethyl bicyclo[2.2.1]hept-5-ene-2-carboxylate)) were obtained by esterification of the hydroxyl moiety of $\mathbf{2 - 5}$, respectively, with 5-norbornene-2-carbonyl chloride using SchottenBaumann conditions (which is shown in Scheme 2). 2-(6Diethylamino-1,3-dioxo-1H-benzo[de]isoquinolin-2(3H)yl)ethyl bicyclo[2.2.1]hept-5-ene-2-carboxylate (10) was prepared by amination of brominated monomer $6[32,33]$.

As shown in Figs. 1 and 2 as well as in Table 1, the substituent at position 6 in the $N$-alkyl- $1 H$-benzo[de]isoquinoline-1,3(2H)-dione system has a strong influence on the spectroscopic characteristics. Replacing the bromine substituent in $\mathbf{6}$ with electron-donating substituents creates a donor-acceptor system with the naphthalimide moiety acting as an acceptor, leading to a bathochromic shift. Comparing the absorption maxima of 6-10 in DMSO to those in DCM, the absorption maximum of the methoxy substituted derivative $\mathbf{7}$ is red-shifted in DMSO by about $20 \mathrm{~nm}$ compared to the absorption maximum in DCM which is a consequence of the increased solvent polarity. Notably, this effect was not as pronounced for the aminosubstituted compounds 8-10. Furthermore, the UV-Vis absorption of naphthalimide-type chromophores is very sensitive to the conformation of the amino moiety which is reflected in $\mathbf{1 0}$ having a significantly red-shifted absorption maximum compared to $\mathbf{8}$ and $\mathbf{9}$ which expectedly show similar UV-Vis spectra [32].

Due to the heavy bromine substituent, the fluorescence of $\mathbf{6}$ is quenched. 7-10 show intense fluorescence and the Stokes shifts are between 70 and $100 \mathrm{~nm}$ for all compounds. The emission maximum of diethylaminosubstituted compound $\mathbf{1 0}$ is bathochromically shifted compared to 7-9, 7 being the emitter with the lowest emission wavelength maximum.

Monomers 6-10 were copolymerized with dimethyl bicyclo[2.2.1]hept-5-ene-2,3-dicarboxylate

(11) in 


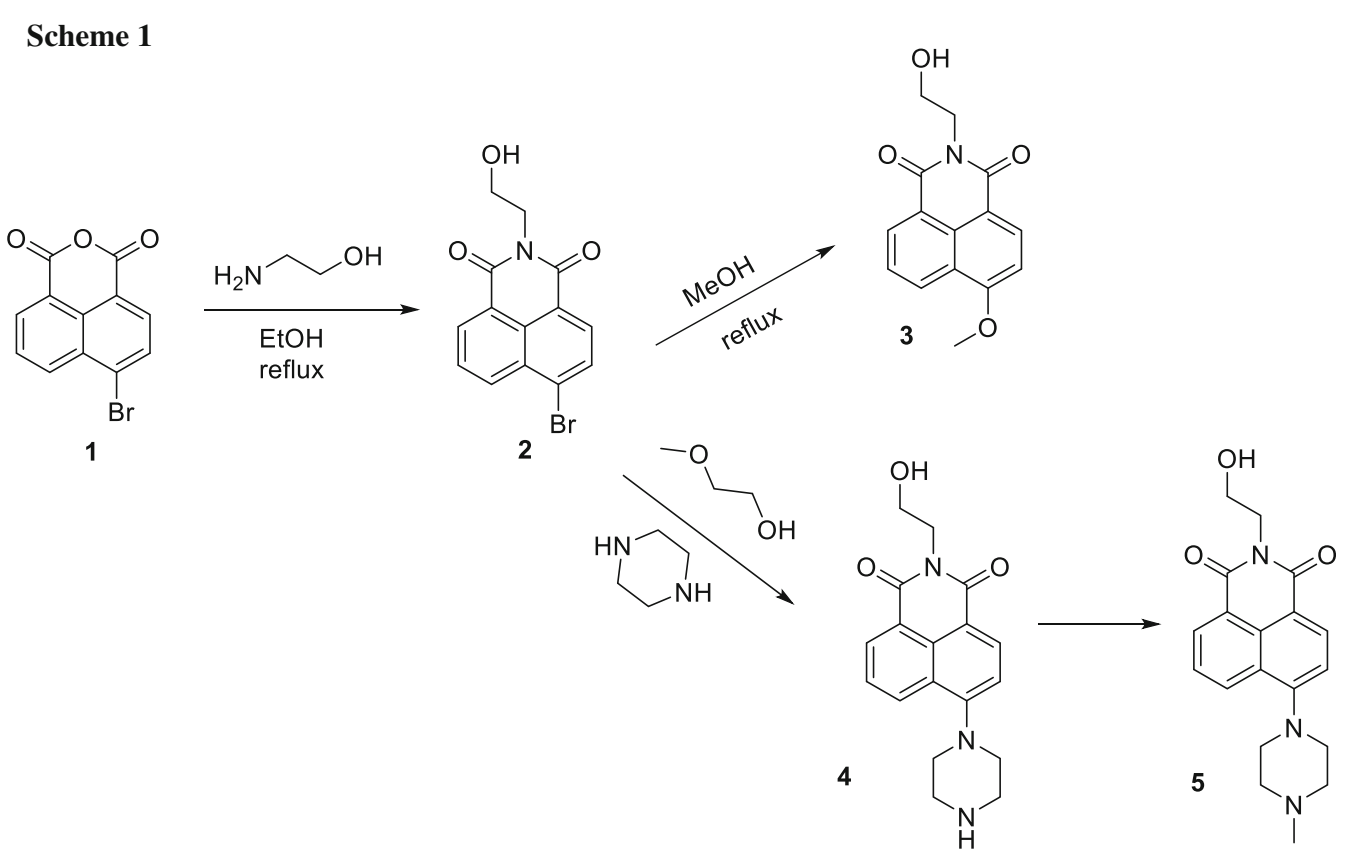

Scheme 2

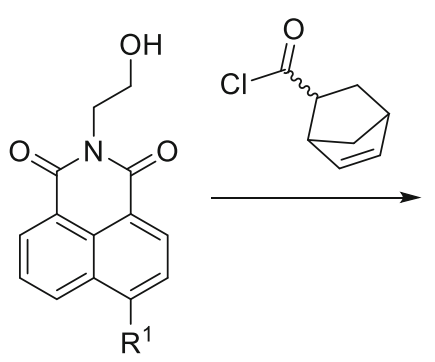

$2 \mathrm{R}^{1}=\mathrm{Br}-$

$3 \mathrm{R}^{1}=$ methoxy -

$4 \mathrm{R}^{1}=$ piperazin-1-yl

$5 \mathrm{R}^{1}=4$-methylpiperazin-1-yl<smiles>[R]c1ccc2c3c(cccc13)C(=O)N(CCOC(=O)[C@@H]1CC3C=CC1C3)C2=O</smiles>

$6 \mathrm{R}^{1}=\mathrm{Br}-$

$7 \mathrm{R}^{1}=$ methoxy -

$8 \mathrm{R}^{1}=$ piperazin-1-yl

$9 \mathrm{R}^{1}=4$-methylpiperazin-1-yl

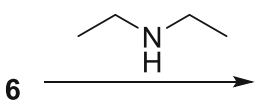<smiles>CCN(CC)c1ccc2c3c(cccc13)C(=O)N(CCOC(=O)[C@@H]1CC3C=CC1C3)C2=O</smiles>

10 different ratios $(1 / 499,5 / 495,10 / 490,50 / 450)$ using [1,3bis(2,4,6-trimethylphenyl)-2-imidazolidinylidene]dichloro (3-phenyl-1H-inden-1-ylidene)(pyridyl)ruthenium(II) (M31) as initiator to yield random copolymers. For the pH-sensitive monomer 9, additional matrix monomers (bicyclo[2.2.1]hept-5-ene-2,3-diyl)bis(phenylmethanone)

(12) and 5,6-bis(ethoxymethyl)bicyclo[2.2.1]hept-2-ene (13)) were selected for copolymerization. An overview of the used matrix monomers is shown in Scheme 3.

Overall, we observed an increasing polydispersity index (PDI) and shorter chain lengths with increasing dye load. This was especially the case for monomer $\mathbf{8}$ and 10; however, dye-functionalized polymeric materials could be successfully prepared using these monomers. Monomer 9 was successfully copolymerized with the two additional comonomers (12 and 13, see Scheme 3) as indicated by similar polydispersity indices for all three copolymers. DSC (differential scanning calorimetry) measurements revealed that the glass transition temperature $\left(T_{\mathrm{g}}\right)$ was expectedly mainly governed by the bulk comonomers. A small increase in $T_{\mathrm{g}}$ was detected for monomers 6-7 with increasing dye load, whereas increased dye loadings for 8-10 led to a decreased $T_{\mathrm{g}}$.

UV-Vis absorption and photoluminescence spectra $\left(\lambda_{\mathrm{ex}}=395 \mathrm{~nm}\right)$ of drop-casted films of polymers $\operatorname{co}\left(\mathbf{M}_{\mathbf{1}^{-}}\right.$ 


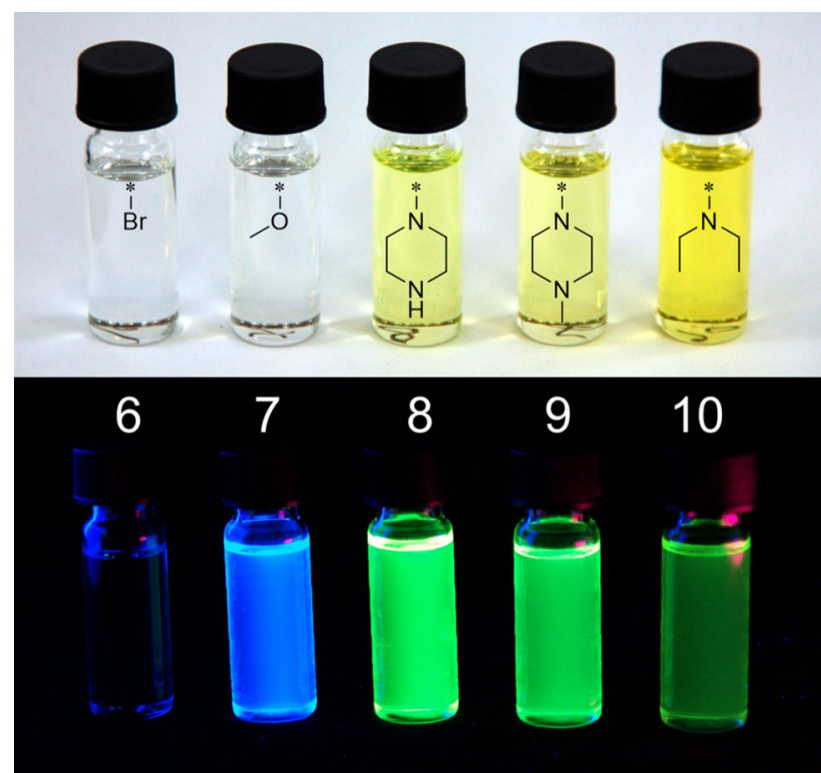

Fig. 1 Monomers 6-10 in solution (DMSO) under visible light (top) and UV irradiation $(\lambda=365 \mathrm{~nm})$

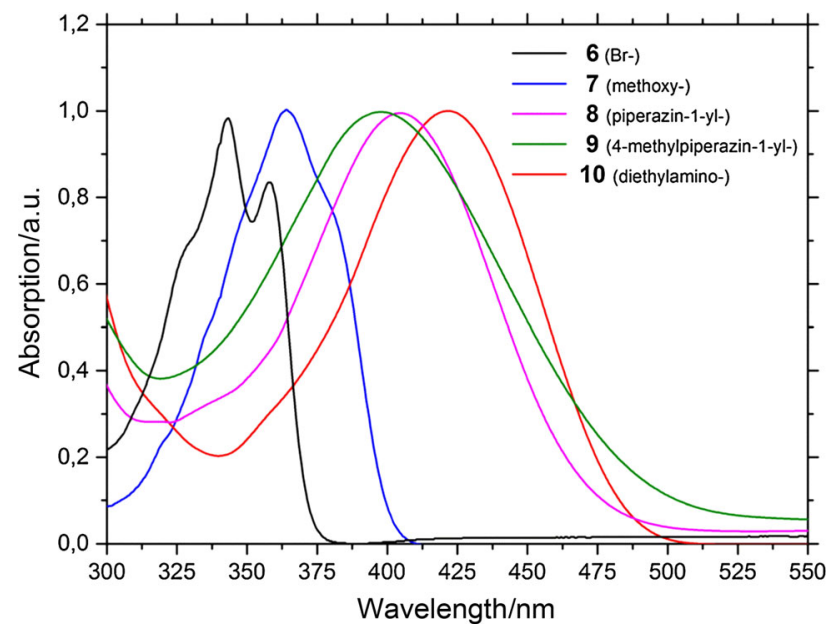

Fig. 2 Normalized UV-Vis absorption spectra of monomers 6-10 in dichloromethane
11499) $(M=\mathbf{6 , 7 , 8 , 9}$, or 10$)$ are shown in Fig. 3. Since 6 and its copolymers did not show any fluorescence, no fluorescence data is shown for polymer $\operatorname{co}\left(6_{1}-\mathbf{1 1}_{499}\right)$.

The absorption and photoluminescence of the dyefunctionalized monomers and the derived polymers are very similar to the free dye monomers 6-10 in solution. Thus, stacking of the naphthalimides which would lead to strong shifts in the photophysical properties is avoided.

In addition, monomer 9 and all related copolymers with this monomer are $\mathrm{pH}$-sensitive due to the possibility to protonate the piperazine group. In Fig. 4, the UV-Vis spectra of the protonated and unprotonated form of the monomer are shown. The absorption maximum of 9 at $402 \mathrm{~nm}$ is blue shifted to $375 \mathrm{~nm}$ if the pyrazine is protonated, e.g., by the addition of trifluoroacetic acid. Upon addition of a base (e.g., triethylamine), the original spectrum is observed so that this reaction can be considered reversible. Thus, copolymers with 9 are possible candidates for polymer based $\mathrm{pH}$-sensing materials, using similar read-out techniques as proposed by Trupp et al. using the same dye functionality in a hydrogel matrix [34]. The possibility to use copolymers of $\mathbf{9}$ as sensor materials will be exploited in the future.

\section{Conclusion}

In this contribution, different naphthalimide dyes have been successfully linked to norbornene monomers. All derivatives were subsequently copolymerized with different norbornene monomers leading to random copolymers. Narrow polydispersity indices and good control of the molecular weight suggest a living polymerization which can be used to design special macromolecular architectures. The optical properties of the polymers are practically identical to those of the dye monomers showing that $\pi-\pi$ stacking of the naphthalimide dyes is avoided.

Table 1 Absorption and photoluminescence spectra of naphthalimide-functionalized monomers in different solvents at room temperature and random copolymers $\mathbf{c o}\left(\mathbf{M}_{\mathbf{1}}-\mathbf{1 1}_{\mathbf{4 9 9}}\right)$, measured in thin film

\begin{tabular}{|c|c|c|c|c|c|c|}
\hline & $\lambda_{\max }^{\mathrm{abs}} / \mathrm{nm}$ & & & $\varepsilon / \mathrm{dm}^{3} \mathrm{~mol} / \mathrm{cm}$ & $\lambda_{\max }^{\mathrm{em}} / \mathrm{nm}$ & \\
\hline & $\mathrm{CH}_{2} \mathrm{Cl}_{2}$ & DMSO & Polymer thin film & DMSO & $\mathrm{CH}_{2} \mathrm{Cl}_{2}$ & Polymer thin film \\
\hline 6 & 343 & 340 & 343 & 21,000 & n.d. ${ }^{a}$ & n.d. ${ }^{a}$ \\
\hline 7 & 363 & 363 & 365 & 13,700 & 433 & 424 \\
\hline 8 & 405 & 408 & 407 & 9500 & 505 & 496 \\
\hline 9 & 399 & 402 & 397 & 7400 & 497 & 485 \\
\hline 10 & 422 & 428 & 422 & 6200 & 532 & 509 \\
\hline
\end{tabular}

${ }^{\text {a }} \mathbf{6}$ is nonfluorescent 
Scheme 3

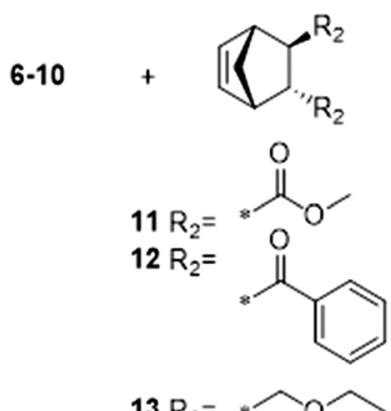

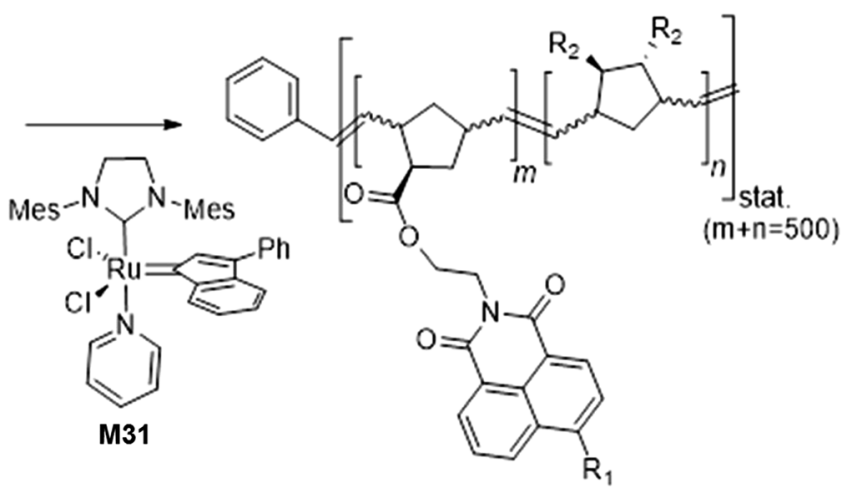

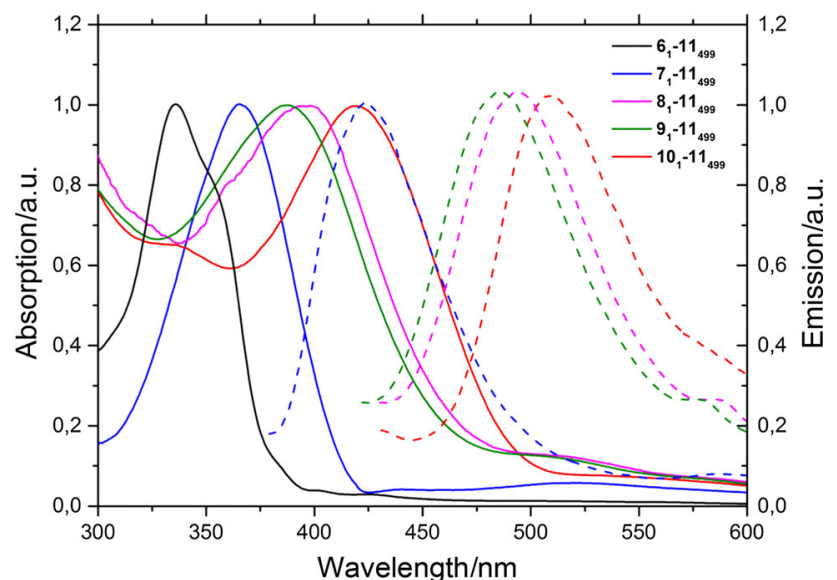

Fig. 3 UV-Vis absorption and photoluminescence emission spectra of drop cast polymer films of $\operatorname{co}\left(\mathbf{M}_{\mathbf{1}}-\mathbf{1 1}_{\mathbf{4 9 9}}\right) M=\mathbf{6 , 7 , 8 , 9}$, or 10

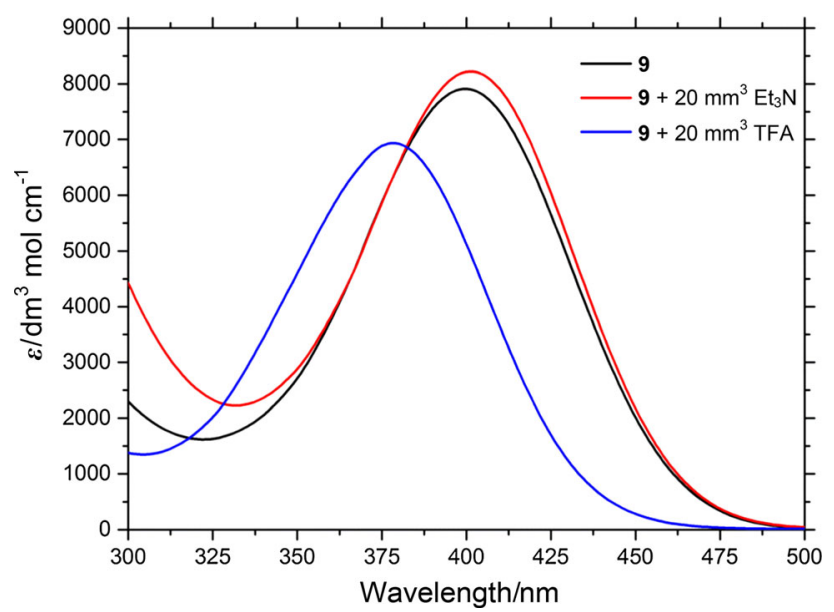

Fig. 4 UV-Vis spectra of monomer 9 in DMSO, after addition of trifluoroacetic acid (TFA) and after addition of triethylamine

\section{Experimental}

Absorption spectra were recorded on a Shimadzu spectrophotometer UV-1800. The emission was measured on a Hitachi F-7000 fluorescence spectrometer equipped with a photomultiplier R928 from Hamamatsu. NMR spectroscopy ( $\left.{ }^{1} \mathrm{H}, \mathrm{APT}\right)$ was done on a Bruker Avance $300 \mathrm{MHz}$ spectrometer. Deuterated solvents (chloroform-d, DMSO- $d_{6}$ ) were obtained from Cambridge Isotope Laboratories Inc. Peak shapes are specified as follows: s (singlet), bs (broad singlet), d (doublet), dd (doublet of doublets), t (triplet), q (quadruplet), m (multiplet). Gel permeation chromatography (GPC) was used to determine molecular weights and the polydispersity index (PDI) of the polymers. Measurements were carried out in THF with the following arrangement: a Merck Hitachi L6000 pump, separation columns from Polymer Standards Service ( $5 \mu \mathrm{m}$ grade size) and a refractive-index detector form Wyatt Technology. For calibration, polystyrene standards purchased from polymer standard service were used. Glass transition temperatures $\left(T_{\mathrm{g}}\right)$ and melting points (m.p.) were measured on a Perkin Elmer Differential Scanning Calorimeter Hyper DSC 8500. Three isothermal cycles were executed, the second scan was analyzed. The scanning speed for cooling and for heating was set to $20{ }^{\circ} \mathrm{C} / \mathrm{min}$ and the temperature range was set from 20 to $200{ }^{\circ} \mathrm{C}$. MALDI-TOF mass spectrometry was performed on a Micromass TofSpec 2E Time-of-Flight Mass Spectrometer. The instrument is equipped with a nitrogen laser (337 nm wavelength operated at a frequency of $5 \mathrm{~Hz}$ ) and a time lag focusing unit. Ions were generated by irradiation just above the threshold laser power. Positive ion spectra were recorded in reflectron mode applying an accelerating voltage of $20 \mathrm{kV}$ and externally calibrated with a suitable mixture of poly(ethylene glycol)s (PEG). Analysis of data was done with Mass Lynx-Software V3.5 (Micromass/Waters, Manchester, UK). All chemicals were purchased from commercial sources (Sigma Aldrich, VWR, ABCR) and used as received. Solvents were purified using appropriate drying agents and degassed with nitrogen before use. Catalyst M31 was provided by Umicore, Germany.

6-Bromo-2-(2-hydroxyethyl)-1H-benzo[de]isoquinoline1,3(2H)-dione $\left(2, \mathrm{C}_{14} \mathrm{H}_{10} \mathrm{BrNO}_{3}\right)$

1 (2.002 g, $7.226 \mathrm{mmol}, 1.0$ equiv.) was dissolved in $110 \mathrm{~cm}^{3}$ of EtOH in a $250 \mathrm{~cm}^{3}$ two-neck round-bottom 
flask equipped with a stirrer bar. After heating to reflux, then $467 \mathrm{~mm}^{3}$ ethanolamine (7.949 mmol, 1.1 equiv.) was added and the reaction mixture was stirred for $4 \mathrm{~h}$. The solution turned from pale beige to dark brown and was cooled to room temperature. The formed precipitate was filtered off, washed three times with dest. $\mathrm{H}_{2} \mathrm{O} / \mathrm{EtOH}$ and was dried under vacuum. Yield: $1.804 \mathrm{~g}(78 \%)$ of $2 .{ }^{1} \mathrm{H}$ NMR $\left(300 \mathrm{MHz}\right.$, DMSO- $\left.d_{6}\right): \delta=8.60-8.52(\mathrm{~m}, 2 \mathrm{H}$, $\left.\mathrm{H}_{\text {naph }} 7, \mathrm{H}_{\text {naph }} 9\right), 8.34-8.31\left(\mathrm{~d}, 1 \mathrm{H},{ }^{3} J_{\mathrm{HH}}=8.1 \mathrm{~Hz}, \mathrm{H}_{\text {naph }} 4\right)$, $8.23-8.20\left(\mathrm{~d}, 1 \mathrm{H},{ }^{3} J_{\mathrm{HH}}=8.1 \mathrm{~Hz}, \mathrm{H}_{\text {naph }} 8\right), 8.02-7.97(\mathrm{t}$, $\left.{ }^{3} J_{\mathrm{HH}}=7.9 \mathrm{~Hz} \quad 1 \mathrm{H}, \quad \mathrm{H}_{\text {naph }} 5\right), \quad 4.83-4.79 \quad(\mathrm{t}, \quad 1 \mathrm{H}$, $\left.{ }^{3} J_{\mathrm{HH}}=5.7 \mathrm{~Hz}, \quad \mathrm{OH}-\mathrm{CH}_{2}-\right), \quad 4.16-4.12 \quad(\mathrm{t}, \quad 2 \mathrm{H}$, $\left.{ }^{3} J_{\mathrm{HH}}=6.4 \mathrm{~Hz},-\mathrm{N}-\mathrm{CH}_{2}-\mathrm{CH}_{2}-\right), 3.65-3.59(\mathrm{~m}, 2 \mathrm{H}, \mathrm{OH}-$ $\left.\mathrm{CH}_{2}-\mathrm{CH}_{2}-\right)$ ppm; ${ }^{1} \mathrm{H}$ NMR spectra were found to be identical with the ones described in Ref. [15].

\section{2-(2-Hydroxyethyl)-6-methoxy-1H-benzo[de]isoquinoline-}

1,3(2H)-dione $\left(3, \mathrm{C}_{15} \mathrm{H}_{13} \mathrm{NO}_{4}\right)$

A $50 \mathrm{~cm}^{3}$ round-bottom flask equipped with magnetic stir bar and reflux condenser was filled with $207 \mathrm{mg}$ of $2(0.64 \mathrm{mmol}$, 1 equiv.) and $45.6 \mathrm{mg}$ potassium hydroxide $(0.81 \mathrm{mmol}, 1.27$ equiv.) and dissolved in $5 \mathrm{~cm}^{3} \mathrm{MeOH}$. The reaction mixture was stirred at $70{ }^{\circ} \mathrm{C}$ for 4 days. The colorless slurry turned pale yellow. After cooling down to room temperature, $15 \mathrm{~cm}^{3}$ $\mathrm{H}_{2} \mathrm{O}$ was added and stored overnight in the fridge. On the next day the yellow precipitate was recovered by filtration and dried in vacuo. Yield: $163.2 \mathrm{mg}(94 \%)$ of 3. ${ }^{1} \mathrm{H}$ NMR (300 MHz, $\left.\mathrm{CDCl}_{3}\right): \delta=8.62-8.55\left(\mathrm{~m}, 3 \mathrm{H}, \mathrm{H}_{\text {naph }} 4, \mathrm{H}_{\text {naph }} 7\right.$, $\left.\mathrm{H}_{\text {naph }} 9\right), 7.73-7.68\left(\mathrm{t},{ }^{3} J_{\mathrm{HH}}=7.9 \mathrm{~Hz}, 1 \mathrm{H}, \mathrm{H}_{\text {naph }} 8\right), 7.06-7.04$ $\left(\mathrm{d}, \quad{ }^{3} J_{\mathrm{HH}}=8.1 \mathrm{~Hz}, \quad 1 \mathrm{H}, \quad \mathrm{H}_{\text {naph }} 5\right), \quad 4.46-4.43(\mathrm{t}, \quad 2 \mathrm{H}$, $\left.{ }^{3} J_{\mathrm{HH}}=5.0 \mathrm{~Hz}, \mathrm{OH}-\mathrm{CH}_{2}-\mathrm{CH}_{2}-\right), 4.00-3.94(\mathrm{~m}, 2 \mathrm{H},-\mathrm{N}-$ $\left.\mathrm{CH}_{2}-\mathrm{CH}_{2}-\right), 2.63-2.60\left(\mathrm{t}, 1 \mathrm{H},{ }^{3} J_{\mathrm{HH}}=5.5 \mathrm{~Hz}, \mathrm{OH}-\mathrm{CH}_{2}-\right.$ $\mathrm{CH}_{2}-$ ) ppm; ${ }^{1} \mathrm{H}$ NMR spectra were found to be identical with the ones described in Ref. [35].

\section{2-(2-Hydroxyethyl)-6-(piperazin-1-yl)-1H-benzo[de]iso- quinoline-1,3(2H)-dione $\left(4, \mathrm{C}_{18} \mathrm{H}_{19} \mathrm{~N}_{3} \mathrm{O}_{3}\right)$}

$2(1 \mathrm{~g}, 3.12 \mathrm{mmol}, 1$ equiv.) and $1.015 \mathrm{~g}$ piperazine hexahydrate $\left(5.23 \mathrm{mmol}, 1.68\right.$ equiv.) were dissolved in $20 \mathrm{~cm}^{3}$ methoxyethanol, and heated to reflux. After $1 \mathrm{~h}$ the reaction mixture started to turn yellow and after continuing the reaction overnight, a yellow solid was formed which was isolated via suction filtration and recrystallized from aqueous ethanol. The crude product was further purified by column chromatography (DCM:MeOH 4/1). After evaporation of the solvent the product was dried in vacuo. Yield: $485 \mathrm{mg}(48 \%)$ of $4 .{ }^{1} \mathrm{H}$ NMR (300 MHz, DMSO- $\left.d_{6}\right): \delta=8.57-8.47\left(\mathrm{~m}, 2 \mathrm{H}, \mathrm{H}_{\text {naph }} 7\right.$, $\left.\mathrm{H}_{\text {naph }} 9\right), 8.43-8.40\left(\mathrm{~d}, 1 \mathrm{H},{ }^{3} J_{\mathrm{HH}}=8.1 \mathrm{~Hz}, \mathrm{H}_{\text {naph }} 4\right), 7.85-7.81$ (t, $\left.1 \mathrm{H}, \mathrm{H}_{\text {naph }} 8\right), 7.50-7.40\left(\mathrm{~m}, 1 \mathrm{H},{ }^{3} J_{\mathrm{HH}}=8.1 \mathrm{~Hz}, \mathrm{H}_{\text {naph }} 5\right)$, 4.80 (bs, $1 \mathrm{H},-\mathrm{CH}-\mathrm{OH}), 4.16-4.11\left(\mathrm{~m}, 2 \mathrm{H},-\mathrm{N}-\mathrm{CH}_{2}-\right)$, 3.62-3.57 (m, $\left.2 \mathrm{H},-\mathrm{CH}_{2}-\mathrm{O}-\right)$, 3.38 [s, 8H, N- $\left.\left(\mathrm{CH}_{2}\right)_{2}\right] \mathrm{ppm}$; ${ }^{1} \mathrm{H}$ NMR spectra were found to be identical with the ones described in Ref. [10]; HRMS (MALDI-TOF): $\mathrm{m} /$ $z=326.1505\left([\mathrm{M}+\mathrm{H}]^{+}\right)$.
2-(2-Hydroxyethyl)-6-(4-methylpiperazin-1-yl)-1Hbenzo[de]isoquinoline-1,3(2H)-dione $\left(5, \mathrm{C}_{19} \mathrm{H}_{21} \mathrm{~N}_{3} \mathrm{O}_{3}\right)$ Compound 4 (100 mg, $0.31 \mathrm{mmol}, 1$ equiv.) and $18.6 \mathrm{mg}$ paraldehyde ( $0.62 \mathrm{mmol}, 2$ equiv.) were dissolved in $4 \mathrm{~cm}^{3}$ formic acid (88-91\%) and stirred at $80{ }^{\circ} \mathrm{C}$ overnight. On the next day the solvent was evaporated. The yellow solid was purified via column chromatography (100:10:1 DCM/ $\mathrm{MeOH} / \mathrm{Et}_{3} \mathrm{~N}$ ) and dried in vacuo to yield $45 \mathrm{mg}$ $(0.13 \mathrm{mmol}, 42 \%)$ of $5 .{ }^{1} \mathrm{H} \mathrm{NMR}\left(300 \mathrm{MHz}, \mathrm{CDCl}_{3}\right)$ : $\delta=8.88-8.76\left(\mathrm{~m}, 2 \mathrm{H}, \mathrm{H}_{\text {naph }} 7, \mathrm{H}_{\text {naph }} 9\right), 8.70-8.67(\mathrm{~m}, 1 \mathrm{H}$, $\left.\mathrm{H}_{\text {naph }} 4\right), \quad 8.02-7.94 \quad\left(\mathrm{~m}, \quad 1 \mathrm{H}, \quad \mathrm{H}_{\text {naph }} 8\right), \quad 7.52-7.47 \quad(\mathrm{t}$, $\left.{ }^{3} J_{\mathrm{HH}}=7.5 \mathrm{~Hz}, 1 \mathrm{H}, \mathrm{H}_{\text {naph }} 5\right), 4.23-4.20(\mathrm{~m}, 2 \mathrm{H},-\mathrm{N}-$ $\left.\mathrm{CH}_{2}-\right), 4.14$ (bs, $\left.1 \mathrm{H},-\mathrm{CH}_{2}-\mathrm{OH}\right), 4.01-3.98(\mathrm{~m}, 2 \mathrm{H},-$ $\mathrm{CH}_{2}-\mathrm{OH}$ ), 3.53-3.49 [m, 8H, N-( $\left.\left.\mathrm{CH}_{2}\right)_{2}-\right], 2.57$ (s, 3H, $\mathrm{CH}_{3}$ ) ppm; ${ }^{1} \mathrm{H}$ NMR spectra were found to be identical with the ones described in Ref. [10].

2-(6-Bromo-1,3-dioxo-1H-benzo[de]isoquinolin-2(3H)yl)ethyl bicyclo[2.2.1]hept-5-ene-2-carboxylate

$\left(6, \mathrm{C}_{22} \mathrm{H}_{18} \mathrm{BrNO}_{4}\right)$

2 (799 mg, $2.5 \mathrm{mmol})$ was dissolved in $30 \mathrm{~cm}^{3}$ DCM and added dropwise to 1.1 equiv. of norbornyl chloride prepared in situ in $25 \mathrm{~cm}^{3}$ dry DCM [from $225 \mathrm{~mm}^{3}$ acryloyl chloride and $625 \mathrm{~mm}^{3}$ (excess) freshly distilled cyclopentadiene]. Immediately after, $203 \mathrm{~mm}^{3}$ ( $2.5 \mathrm{mmol}, 1$ equiv.) pyridine and $20 \mathrm{mg}$ (catalytic amount) of DMAP were added. The reaction mixture was stirred overnight. On the next day, the reaction was quenched with $12 \mathrm{~cm}^{3}$ distilled water. The organic layer was extracted with $\mathrm{HCl}(5 \%), 2 \%$ sodium bicarbonate and dried over sodium sulfate. The crude product was concentrated under reduced pressure and purified via column chromatography (100:1 dichloromethane/methanol). Yield $748.5 \mathrm{mg}$ (63\%); colorless solid; m.p.: $204{ }^{\circ} \mathrm{C} ;{ }^{1} \mathrm{H}$ NMR $\left(300 \mathrm{MHz}, \mathrm{CDCl}_{3}\right): \delta=8.69-8.66$ $\left(\mathrm{d}, 2 \mathrm{H},{ }^{3} J_{\mathrm{HH}}=8.9 \mathrm{~Hz}, \mathrm{H}_{\text {naph }} 7\right), 8.61-8.58(\mathrm{~d}, 1 \mathrm{H}$, $\left.{ }^{3} J_{\mathrm{HH}}=8.9 \mathrm{~Hz}, \quad \mathrm{H}_{\text {naph }} 9\right), \quad 8.45-8.42\left(\mathrm{~d}, 1 \mathrm{H},{ }^{3} J_{\mathrm{HH}}=\right.$ $\left.7.8 \mathrm{~Hz}, \quad \mathrm{H}_{\mathrm{naph}} 4\right), \quad 8.07-8.05 \quad\left(\mathrm{~d}, \quad 1 \mathrm{H},{ }^{3} J_{\mathrm{HH}}=7.8 \mathrm{~Hz}\right.$, $\left.\mathrm{H}_{\text {naph }} 8\right), \quad 7.89-7.84\left(\mathrm{t}, 1 \mathrm{H},{ }^{3} J_{\mathrm{HH}}=7.3 \mathrm{~Hz}, \mathrm{H}_{\text {naph }} 5\right)$, $6.08-6.05\left(\mathrm{~d}, 1 \mathrm{H},{ }^{3} J_{\mathrm{HH}}=2.8 \mathrm{~Hz}, \mathrm{H}_{\mathrm{nb}} 6\right), 5.83-5.80(\mathrm{~d}$, $\left.1 \mathrm{H},{ }^{3} J_{\mathrm{HH}}=2.8 \mathrm{~Hz}, \mathrm{H}_{\mathrm{nb}} 5\right), 4.40-4.36\left(\mathrm{~m}, 2 \mathrm{H},-\mathrm{N}-\mathrm{CH}_{2}-\right.$ $\left.\mathrm{CH}_{2}-\right), 4.50-4.46\left(\mathrm{~m}, 2 \mathrm{H},-\mathrm{N}-\mathrm{CH}_{2}-\mathrm{CH}_{2}-\right), 3.11$ (bs, $1 \mathrm{H}$, $\left.\mathrm{H}_{\mathrm{nb}} 2\right), 2.91-2.85\left(\mathrm{~m}, 1 \mathrm{H}, \mathrm{H}_{\mathrm{nb}} 1\right), 2.83$ (bs, $1 \mathrm{H}, \mathrm{H}_{\mathrm{nb}} 3^{\mathrm{b}}$ ), $1.89-1.80\left(\mathrm{~m}, 1 \mathrm{H}, \mathrm{H}_{\mathrm{nb}} 4\right), 1.37-1.19\left(\mathrm{~m}, 3 \mathrm{H}, \mathrm{H}_{\mathrm{nb}} 7^{\mathrm{a}, \mathrm{b}}\right.$, $\mathrm{H}_{\mathrm{nb}} 3 \mathrm{a}$ ) ppm (no signals for the exo-compound could be detected); ${ }^{13} \mathrm{C}$ NMR $\left(75 \mathrm{MHz}, \mathrm{CDCl}_{3}\right): \delta=174.79(1 \mathrm{C}$, -COO-), 163.70 (2C, O=C-N-C=O), 137.75, 133.55, $132.28,131.45,131.28,130.58,129.17,128.25,123.03$, $122.16\left(10 \mathrm{C}, \mathrm{C}_{\mathrm{naph}}\right), 132.55,130.80\left(2 \mathrm{C}, \mathrm{C}_{\mathrm{nb}} 5, \mathrm{C}_{\mathrm{nb}} 6\right)$, $61.44\left(1 \mathrm{C},-\mathrm{COO}-\mathrm{CH}_{2}-\mathrm{CH}_{2}-\right), 49.69\left(1 \mathrm{C}, \mathrm{C}_{\mathrm{nb}} 7\right), 45.69$ $\left(1 \mathrm{C}, \mathrm{C}_{\mathrm{nb}} 1\right), 43.33\left(1 \mathrm{C}, \mathrm{C}_{\mathrm{nb}} 2\right), 42.61\left(1 \mathrm{C}, \mathrm{C}_{\mathrm{nb}} 4\right), 39.38$ $\left(1 \mathrm{C},-\mathrm{N}-\mathrm{CH}_{2}-\mathrm{CH}_{2}-\right), 29.41\left(1 \mathrm{C}, \mathrm{C}_{\mathrm{nb}} 3\right)$ ppm; HRMS (MALDI-TOF): $m / z=465.0382\left([\mathrm{M}+\mathrm{Na}]^{+}\right)$. 
2-(6-Methoxy-1,3-dioxo-1H-benzo[de]isoquinolin-2(3H)yl)ethyl bicyclo[2.2.1]hept-5-ene-2-carboxylate

$\left(7, \mathrm{C}_{23} \mathrm{H}_{21} \mathrm{NO}_{5}\right)$

$3(1.5 \mathrm{~g}, 5.53 \mathrm{mmol})$ was dissolved in $200 \mathrm{~cm}^{3}$ DCM and added dropwise to 1.1 equiv. of norbornyl chloride prepared in situ [from $493 \mathrm{~mm}^{3}$ acryloyl chloride and $1.37 \mathrm{~cm}^{3}$ (excess) freshly distilled cyclopentadiene]. Immediately after the addition $445 \mathrm{~mm}^{3}$ (5.53 mmol, 1 equiv.) pyridine and $50 \mathrm{mg}$ (catalytic amount) of DMAP was added. The reaction mixture was stirred overnight. On the next day, the reaction was quenched with $35 \mathrm{~cm}^{3}$ distilled water. The organic layer was extracted with $\mathrm{HCl}(5 \%), 2 \%$ sodium bicarbonate and dried over sodium sulfate. The crude product was concentrated under reduced pressure and purified via column chromatography (5:1 cyclohexane/ethyl acetate). Yield $1.4 \mathrm{~g}(65 \%)$; pale yellow solid; m.p.: $184{ }^{\circ} \mathrm{C}$; ${ }^{1} \mathrm{H}$ NMR $\left(300 \mathrm{MHz}, \mathrm{CDCl}_{3}\right): \delta=8.61-8.54(\mathrm{~m}, 3 \mathrm{H}$, $\left.\mathrm{H}_{\text {naph }} 4, \mathrm{H}_{\text {naph }} 7, \mathrm{H}_{\text {naph }} 9\right), 7.73-7.67\left(\mathrm{t}, 1 \mathrm{H},{ }^{3} J_{\mathrm{HH}}=8.4 \mathrm{~Hz}\right.$, $\left.\mathrm{H}_{\text {naph }} 8\right), \quad 7.05-7.03\left(\mathrm{~d}, 1 \mathrm{H},{ }^{3} J_{\mathrm{HH}}=8.4 \mathrm{~Hz}, \mathrm{H}_{\text {naph }} 5\right)$, 6.07-6.04 (m, 1H, $\left.\mathrm{H}_{\mathrm{nb}} 6\right), 5.83-5.79\left(\mathrm{~m}, 1 \mathrm{H}, \mathrm{H}_{\mathrm{nb}} 5\right)$, 4.48-4.35 (m, 4H, -N- $\left.\mathrm{CH}_{2}-\mathrm{CH}_{2}-\right), 4.13$ (s, 3H, $-\mathrm{O}-\mathrm{CH}_{3}$ ), 3.11 (bs, $1 \mathrm{H}, \mathrm{H}_{\mathrm{nb}} 2$ ), 2.93-2.87 (m, 1H, $\left.\mathrm{H}_{\mathrm{nb}} 1\right) 2.82$ (bs, $1 \mathrm{H}$, $\left.\mathrm{H}_{\mathrm{nb}} 3^{\mathrm{b}}\right), 1.88-1.80\left(\mathrm{~m}, 1 \mathrm{H}, \mathrm{H}_{\mathrm{nb}} 4\right), 1.38-1.32\left(\mathrm{~m}, 2 \mathrm{H}, \mathrm{H}_{\mathrm{nb}} 3^{\mathrm{a}}\right.$, $\left.\mathrm{H}_{\mathrm{nb}} 7^{\mathrm{a}}\right), 1.21-1.18\left(\mathrm{~d},{ }^{3} J_{\mathrm{HH}}=8.0 \mathrm{~Hz}, 1 \mathrm{H}, \mathrm{H}_{\mathrm{nb}} 7^{\mathrm{b}}\right) \mathrm{ppm}($ no signals for the exo-compound could be detected); ${ }^{13} \mathrm{C}$ NMR $\left(75 \mathrm{MHz}, \mathrm{CDCl}_{3}\right): \delta=174.77$ (1C, -COO-), 164.61, $163.98, \quad(2 \mathrm{C}, \quad \mathrm{O}=\mathrm{C}-\mathrm{N}-\mathrm{C}=\mathrm{O}), \quad 161.06 \quad 137.68, \quad 132.62$, $131.80,128.93,123.68,122.36,115.03,105.37$ (10C, $\left.\mathrm{C}_{\text {naph }}\right), 133.72\left(2 \mathrm{C}, \mathrm{C}_{\mathrm{nb}} 5, \mathrm{C}_{\mathrm{nb}} 6\right), 61.60\left(1 \mathrm{C},-\mathrm{COO}-\mathrm{CH}_{2}-\right.$ $\left.\mathrm{CH}_{2}-\right), 56.36\left(1 \mathrm{C},-\mathrm{O}-\mathrm{CH}_{3}\right), 49.68\left(1 \mathrm{C}, \mathrm{C}_{\mathrm{nb}} 7\right), 45.71(1 \mathrm{C}$, $\left.\mathrm{C}_{\mathrm{nb}} 1\right), 43.33\left(1 \mathrm{C}, \mathrm{C}_{\mathrm{nb}} 2\right), 42.62\left(1 \mathrm{C}, \mathrm{C}_{\mathrm{nb}} 4\right), 39.00(1 \mathrm{C},-\mathrm{N}-$ $\left.\mathrm{CH}_{2}-\mathrm{CH}_{2}-\right), 29.38\left(1 \mathrm{C}, \mathrm{C}_{\mathrm{nb}} 3\right) \mathrm{ppm}$; HRMS (MALDI-TOF): $m / z=414.1042\left([\mathrm{M}+\mathrm{Na}]^{+}\right)$.

2-[1,3-Dioxo-6-(piperazin-1-yl)-1H-benzo[de]isoquinolin2(3H)-yl]ethyl bicyclo[2.2.1]hept-5-ene-2-carboxylate

$\left(\mathbf{8}, \mathrm{C}_{26} \mathrm{H}_{27} \mathrm{~N}_{3} \mathrm{O}_{4}\right)$

$4\left(300 \mathrm{mg}, 0.92 \mathrm{mmol}\right.$ ) was dissolved in $40 \mathrm{~cm}^{3}$ DCM and added dropwise to 1.1 equiv. of norbornyl chloride prepared in situ in $10 \mathrm{~cm}^{3}$ dry DCM [from $99 \mathrm{~mm}^{3}$ acryloyl chloride and $227 \mathrm{~mm}^{3}$ (excess) freshly distilled cyclopentadiene]. Immediately after the addition $75 \mathrm{~mm}^{3}$ (0.92 mmol, 1 equiv.) pyridine and $10 \mathrm{mg}$ (catalytic amount) of DMAP was added. The reaction mixture was stirred overnight. After full consumption of the starting material had been detected by TLC (DCM/methanol 20/1), $12 \mathrm{~cm}^{3}$ of water were added to quench the reaction which was then stirred for $90 \mathrm{~min}$. The organic layer was extracted with $\mathrm{HCl}(5 \%)$ and $2 \%$ sodium bicarbonate, and subsequently dried over sodium sulfate. After solvent removal under reduced pressure, the product was purified using column chromatography (40/1 DCM/MeOH). Yield $269 \mathrm{mg}$ (68\%); yellow waxy substance; m.p.: $90{ }^{\circ} \mathrm{C}$ (dec.);
${ }^{1} \mathrm{H}$ NMR $\left(300 \mathrm{MHz}\right.$, DMSO- $\left.d_{6}\right): \delta=8.62-8.39(\mathrm{~m}, 3 \mathrm{H}$, $\mathrm{H} 4, \mathrm{H} 7, \mathrm{H} 9), 7.73\left(\mathrm{t}, 1 \mathrm{H},{ }^{3} J_{H H}=7.9 \mathrm{~Hz}, \mathrm{H} 8\right), 7.27-7.17$ (m, 1H, H5), 6.11-6.08 (m, 1H, $\left.\mathrm{H}_{\mathrm{nb}} 6\right), 5.65-5.62(\mathrm{~m}, 1 \mathrm{H}$, $\left.\mathrm{H}_{\mathrm{nb}} 5\right)$ 4.38-4.24 (m, 4H, -N- $\left.\mathrm{CH}_{2}-\mathrm{CH}_{2}-\mathrm{O}-\right)$, 3.33 [bs, 8H, $\left.\mathrm{N}-\left(\mathrm{CH}_{2}\right)_{2}-\left(\mathrm{CH}_{2}-\right)_{2}\right], 3.09$ (bs, $\left.1 \mathrm{H}, \mathrm{H}_{\mathrm{nb}} 2\right) \quad 3.00-2.75$ (m, $\left.3 \mathrm{H}, \mathrm{H}_{\mathrm{nb}} 1, \mathrm{H}_{\mathrm{nb}} 3^{\mathrm{b}}, \mathrm{H}_{\mathrm{nb}} 4\right), 1.52-1.27\left(\mathrm{~m}, 3 \mathrm{H}, \mathrm{H}_{\mathrm{nb}} 3^{\mathrm{a}}, \mathrm{H}_{\mathrm{nb}} 7^{\mathrm{a}, \mathrm{b}}\right.$ ) ppm [characteristic exo-signals: $6.00-5.88(\mathrm{~m}, 0.2 \mathrm{H})$ ]; ${ }^{13} \mathrm{C}$ NMR $\left(75 \mathrm{MHz}\right.$, DMSO- $\left.d_{6}\right): \delta=173.07$ (1C, $\left.-\mathrm{COO}-\right)$, $163.84(2 \mathrm{C}, \quad \mathrm{O}=\mathrm{C}-\mathrm{N}-\mathrm{C}=\mathrm{O}), \quad 155.37, \quad 137.58, \quad 136.78$, 132.99, 132.54, 130.02, $126.11\left(10 \mathrm{C}, \mathrm{C}_{\text {naph }}\right), 131.38(2 \mathrm{C}$, $\left.\mathrm{C}_{\mathrm{nb}} 5, \mathrm{C}_{\mathrm{nb}} 6\right), 61.48\left(1 \mathrm{C},-\mathrm{O}-\mathrm{CH}_{2}-\mathrm{CH}_{2}-\right), 50.01\left(1 \mathrm{C}, \mathrm{C}_{\mathrm{nb}} 7\right)$ $45.78\left[2 \mathrm{C},-\mathrm{N}-\left(\mathrm{CH}_{2}\right)-\right], 45.00\left(1 \mathrm{C}, \mathrm{C}_{\mathrm{nb}} 1\right), 43.21[2 \mathrm{C},-\mathrm{N}-$ $\left.\left(\mathrm{CH}_{2}\right)-\right], 42.89\left(1 \mathrm{C}, \mathrm{C}_{\mathrm{nb}} 2\right), 42.57\left(1 \mathrm{C}, \mathrm{C}_{\mathrm{nb}} 4\right), 39.01(-\mathrm{N}-$ $\mathrm{CH}_{2}-\mathrm{CH}_{2}-$ ), $31.05\left(1 \mathrm{C}, \mathrm{C}_{\mathrm{nb}} 3\right)$ ppm; HRMS (MALDITOF): $m / z=445.2049\left([\mathrm{M}]^{+}\right)$.

2-[6-(4-Methylpiperazin-1-yl)-1,3-dioxo-1H-benzo[de]isoquinolin-2(3H)-yl]ethyl bicyclo[2.2.1]hept-5-ene-2carboxylate $\left(\mathbf{9}, \mathrm{C}_{27} \mathrm{H}_{29} \mathrm{~N}_{3} \mathrm{O}_{4}\right)$

5 (300 mg, $0.884 \mathrm{mmol}$ ) was dissolved in $40 \mathrm{~cm}^{3}$ dry DCM and added dropwise to $10 \mathrm{~cm}^{3}$ dry DCM of 1.2 equiv. norbornyl chloride prepared in situ [from $94.3 \mathrm{~mm}^{3}$ acryloyl chloride and $219 \mathrm{~mm}^{3}$ (excess) freshly distilled cyclopentadiene]. Immediately after, $71.4 \mathrm{~mm}^{3}$ (0.884 mmol, 1 equiv.) pyridine and $20 \mathrm{mg}$ (catalytic amount) of DMAP were added. The reaction mixture was stirred overnight. Progress of the reaction was monitored via TLC (DCM:MeOH 20/1). The esterification was completed on the next day and excess acid chloride was quenched with $7 \mathrm{~cm}^{3}$ water. The organic layer was then extracted with saturated sodium bicarbonate and dried over sodium sulfate. The drying agent was removed via filtration and the solvent was evaporated to yield a sticky yellow solid which was purified via column chromatography (10/1 DCM/MeOH). Yield $212 \mathrm{mg}$ (52\%); yellow waxy substance; m.p.: $90{ }^{\circ} \mathrm{C}$ (dec.); ${ }^{1} \mathrm{H}$ NMR $(300 \mathrm{MHz}$, DMSO$\left.d_{6}\right): \delta=8.62-8.56(\mathrm{~d}, 3 \mathrm{H}, \mathrm{H} 4, \mathrm{H} 7, \mathrm{H} 9), 8.02-7.97(\mathrm{t}, 1 \mathrm{H}$, $\left.{ }^{3} J_{H H}=7.8 \mathrm{~Hz}, \quad \mathrm{H} 8\right), 7.53-7.50\left(\mathrm{~d},{ }^{3} J_{H H}=7.8 \mathrm{~Hz}, 1 \mathrm{H}\right.$, $\mathrm{H} 5), 6.17-6.14\left(\mathrm{~m}, 1 \mathrm{H}, \mathrm{H}_{\mathrm{nb}} 6\right), 5.85-5.81\left(\mathrm{~m}, 1 \mathrm{H}, \mathrm{H}_{\mathrm{nb}} 5\right)$, 4.47 (bs, $\left.4 \mathrm{H},-\mathrm{N}-\mathrm{CH}_{2}-\mathrm{CH}_{2}-\mathrm{O}-\right), 3.53$ [bs, $4 \mathrm{H}, \mathrm{N}-\left(\mathrm{CH}_{2}\right)_{2}-$ ], 3.43 (bs, $\left.3 \mathrm{H},-\mathrm{CH}_{3}\right) 3.17$ (bs, $\left.1 \mathrm{H}, \mathrm{H}_{\mathrm{nb}} 2\right), 2.96$ (bs, $1 \mathrm{H}$, $\left.\mathrm{H}_{\mathrm{nb}} 1\right)$ 2.86-2.80 (m, 2H, $\left.\mathrm{H}_{\mathrm{nb}} 3^{\mathrm{b}}, \mathrm{H}_{\mathrm{nb}} 4\right), 2.70[\mathrm{~s}, 4 \mathrm{H}, \mathrm{N}-$ $\left(\mathrm{CH}_{2}\right)_{2}-\mathrm{l}, 1.48-1.30\left(\mathrm{~m}, 3 \mathrm{H}, \mathrm{H}_{\mathrm{nb}} 3^{\mathrm{a}}, \mathrm{H}_{\mathrm{nb}} 7^{\mathrm{a}, \mathrm{b}} \mathrm{CH}_{3}-\right) \mathrm{ppm}$ [characteristic exo-signals: $6.23-6.19(\mathrm{~m}, \quad 0.15 \mathrm{H})$, 5.95-5.91 (m, 0.15H)]; ${ }^{13} \mathrm{C}$ NMR $\left(75 \mathrm{MHz}, \mathrm{CDCl}_{3}\right)$ : $\delta=173.69(1 \mathrm{C},-\mathrm{COO}-), 163.62,163.03(2 \mathrm{C}, \mathrm{O}=\mathrm{C}-\mathrm{N}-$ $\mathrm{C}=\mathrm{O}), 155.75,137.43,129.19,125.98,125.25,115.29$, $115.04\left(10 \mathrm{C}, \mathrm{C}_{\mathrm{naph}}\right), 132.25,130.65\left(2 \mathrm{C}, \mathrm{C}_{\mathrm{nb}} 5, \mathrm{C}_{\mathrm{nb}} 6\right)$, $60.78\left(1 \mathrm{C},-\mathrm{COO}-\mathrm{CH}_{2}-\mathrm{CH}_{2}-\right), 54.49\left(1 \mathrm{C}, \mathrm{C}_{\mathrm{nb}} 7\right), 54.59$ [2C, $\left.-\mathrm{N}-\left(\mathrm{CH}_{2}\right)-\right], 52.51\left[2 \mathrm{C},-\mathrm{N}-\left(\mathrm{CH}_{2}\right)-\right], 48.97(2 \mathrm{C},-\mathrm{N}-$ $\left.\mathrm{CH}_{2}-\mathrm{CH}_{3}\right), 45.72\left(1 \mathrm{C}, \mathrm{C}_{\mathrm{nb}} 1\right), 44.95\left(1 \mathrm{C}, \mathrm{C}_{\mathrm{nb}} 2\right), 42.48$ (1C, $\left.\mathrm{C}_{\mathrm{nb}} 4\right), 41.83\left(1 \mathrm{C},-\mathrm{N}-\mathrm{CH}_{3}\right) 28.68\left(1 \mathrm{C}, \mathrm{C}_{\mathrm{nb}} 3\right) \mathrm{ppm}$; HRMS $(\mathrm{MALDI}-\mathrm{TOF}): \mathrm{m} / \mathrm{z}=460.2236\left([\mathrm{M}+\mathrm{H}]^{+}\right)$. 
2-(6-Diethylamino-1,3-dioxo-1H-benzo[de]isoquinolin2(3H)-yl)ethyl bicyclo[2.2.1]hept-5-ene-2-carboxylate $\left(\mathbf{1 0}, \mathrm{C}_{26} \mathrm{H}_{28} \mathrm{~N}_{2} \mathrm{O}_{4}\right)$

6 (300 mg, $0.96 \mathrm{mmol}, 1$ equiv.) was placed in a $50 \mathrm{~cm}^{3}$ round-bottom flask and dissolved in $10 \mathrm{~cm}^{3}$ DMF. After addition of $498 \mathrm{mg}$ diethylamine ( $6.81 \mathrm{mmol}, 10$ equiv.) the mixture was stirred overnight. On the next day, the solvent was removed by distillation and the product was purified via column chromatography (10/1 DCM/MeOH). Yield $240 \mathrm{mg}$ (57\%); yellow waxy substance; m.p.: $90{ }^{\circ} \mathrm{C}$ (dec.); ${ }^{1} \mathrm{H}$ NMR $\left(300 \mathrm{MHz}, \mathrm{CDCl}_{3}\right): \delta=8.58-8.56$ (d, $2 \mathrm{H}, \mathrm{H} 7, \mathrm{H} 9) \quad 8.50-8.44\left(\mathrm{t}, 1 \mathrm{H},{ }^{3} J_{\mathrm{HH}}=8.5 \mathrm{~Hz}, \mathrm{H} 4\right)$, $7.68-7.63\left(\mathrm{t}, 1 \mathrm{H},{ }^{3} J_{\mathrm{HH}}=8.0 \mathrm{~Hz}, \mathrm{H} 8\right), 7.22-7.19(\mathrm{~d}, 1 \mathrm{H}$, $\left.{ }^{3} J_{\mathrm{HH}}=8.0 \mathrm{~Hz}, \mathrm{H} 5\right), 6.07-6.05\left(\mathrm{~m}, 1 \mathrm{H}, \mathrm{H}_{\mathrm{nb}} 6\right), 5.84-5.81$ $\left(\mathrm{m}, \quad 1 \mathrm{H}, \mathrm{H}_{\mathrm{nb}} 5\right), 4.47-4.34\left(\mathrm{~m}, 4 \mathrm{H},-\mathrm{N}-\mathrm{CH}_{2}-\mathrm{CH}_{2}-\right)$, 3.45-3.38 (m, 4H, -N- $\left.\mathrm{CH}_{2}-\mathrm{CH}_{3}\right), 3.10-3.05(\mathrm{~m}, 2 \mathrm{H}$, $\mathrm{H}_{\mathrm{nb}} 1, \mathrm{H}_{\mathrm{nb}}$ ) ) 2.78-2.88 (bs, $1 \mathrm{H}, \mathrm{H}_{\mathrm{nb}} 3^{\mathrm{b}}$ ), 1.87-1.80 (m, $1 \mathrm{H}$, $\left.\mathrm{H}_{\mathrm{nb}} 4\right)$, $1.52-1.47\left(\mathrm{t}, 6 \mathrm{H},{ }^{3} J_{\mathrm{HH}}=7.4 \mathrm{~Hz},-\mathrm{N}-\mathrm{CH}_{2}-\mathrm{CH}_{3}\right)$, 1.36-1.32 (m, $\left.3 \mathrm{H}, \mathrm{H}_{\mathrm{nb}} 3^{\mathrm{a}}, \mathrm{H}_{\mathrm{nb}} 7^{\mathrm{a}, \mathrm{b}}\right)$ ppm [characteristic exosignals could not be detected due to peak broadening]; ${ }^{13} \mathrm{C}$ NMR (75 MHz, $\mathrm{CDCl}_{3}$ ): $\delta=174.82$ (1C, -COO-), 164.72 $(2 \mathrm{C}, \quad \mathrm{O}=\mathrm{C}-\mathrm{N}-\mathrm{C}=\mathrm{O}), \quad 137.67, \quad 131.31, \quad 131.21,125.32$, 116.93, (10C, $\left.\mathrm{C}_{\text {naph }}\right), 132,64,132.33\left(2 \mathrm{C}, \mathrm{C}_{\mathrm{nb}} 5, \mathrm{C}_{\mathrm{nb}} 6\right)$, $61.63\left(1 \mathrm{C},-\mathrm{COO}-\mathrm{CH}_{2}-\mathrm{CH}_{2}-\right), 49.68$ (1C, $\left.\mathrm{C}_{\mathrm{nb}} 7\right), 47.40$ $\left(2 \mathrm{C},-\mathrm{N}-\mathrm{CH}_{2}-\mathrm{CH}_{3}\right), 45.71\left(1 \mathrm{C}, \mathrm{C}_{\mathrm{nb}} 1\right), 43.33\left(1 \mathrm{C}, \mathrm{C}_{\mathrm{nb}} 2\right)$, $42.48\left(1 \mathrm{C}, \mathrm{C}_{\mathrm{nb}} 4\right), 38.96\left(1 \mathrm{C},-\mathrm{N}-\mathrm{CH}_{2}-\mathrm{CH}_{2}-\right), 29.39$ (1C, $\left.\mathrm{C}_{\mathrm{nb}} 3\right), 12.37\left(2 \mathrm{C},-\mathrm{N}-\mathrm{CH}_{2}-\mathrm{CH}_{3}\right)$ ppm [characteristic exo-

Table 2 Polymerization data of random copolymers of dye monomers 6-10 and matrix monomers 11-13

\begin{tabular}{|c|c|c|c|c|}
\hline Polymers & Yield $/ \%$ & $\mathrm{Mn} / \mathrm{kDa}^{\mathrm{a}}$ & $\mathrm{PDI}^{\mathrm{a}}$ & $T_{\mathrm{g}} /{ }^{\circ} \mathrm{C}^{\mathrm{b}}$ \\
\hline $\operatorname{co}\left(6_{1}-11_{499}\right)$ & 85 & 115.7 & 1.16 & 93.6 \\
\hline $\operatorname{co}\left(6_{5}-11_{495}\right)$ & 82 & 110.1 & 1.20 & 94.3 \\
\hline $\operatorname{co}\left(6_{10}-11_{490}\right)$ & 80 & 106.5 & 1.40 & 97.5 \\
\hline $\operatorname{co}\left(6_{50}-11_{450}\right)$ & 78 & 96.7 & 1.80 & 97.8 \\
\hline $\operatorname{co}\left(7_{1}-11_{499}\right)$ & 84 & 118.3 & 1.13 & 95.3 \\
\hline $\operatorname{co}\left(7_{5}-11_{495}\right)$ & 83 & 105.1 & 1.28 & 95.9 \\
\hline $\operatorname{co}\left(7_{10}-11_{490}\right)$ & 80 & 121.3 & 1.15 & 98.6 \\
\hline $\operatorname{co}\left(7_{50}-11_{450}\right)$ & 82 & 151.7 & 1.40 & 99.1 \\
\hline $\operatorname{co}\left(8_{1}-11_{499}\right)$ & 75 & 116.4 & 1.55 & 94.8 \\
\hline $\operatorname{co}\left(8_{5}-11_{495}\right)$ & 68 & 118.7 & 3.04 & 95.3 \\
\hline $\operatorname{co}\left(8_{10}-11_{490}\right)$ & 65 & 59.1 & 2.38 & 96.1 \\
\hline $\operatorname{co}\left(9_{1}-11_{499}\right)$ & 75 & 49.9 & 1.12 & 94.4 \\
\hline $\operatorname{co}\left(9_{5}-11_{495}\right)$ & 76 & 49.7 & 1.10 & 95.5 \\
\hline $\operatorname{co}\left(9_{10}-11_{490}\right)$ & 74 & 58.3 & 1.22 & 96.2 \\
\hline $\operatorname{co}\left(9_{5}-12_{495}\right)$ & 80 & 49.9 & 1.12 & 150.1 \\
\hline $\operatorname{co}\left(9_{5}-13_{495}\right)$ & 78 & 58.3 & 1.22 & 28.3 \\
\hline $\operatorname{co}\left(10_{1}-11_{499}\right)$ & 73 & 53.2 & 1.62 & 94.4 \\
\hline $\operatorname{co}\left(10_{5}-11_{495}\right)$ & 75 & 74.8 & 1.70 & 93.5 \\
\hline $\operatorname{co}\left(10_{10}-11_{490}\right)$ & 70 & 73.5 & 2.00 & 90.9 \\
\hline
\end{tabular}

signals could not be detected due to peak broadening]; HRMS (MALDI-TOF): $m / z=432.2079\left([\mathrm{M}]^{+}\right.$).

General procedure for ring-opening metathesis polymerization: synthesis of $\operatorname{co}\left(6_{1}-11_{499}\right)$

Matrix monomer 11 (100 mg, $0.48 \mathrm{mmol}, 499$ equiv.) and $0.42 \mathrm{mg}\left(9.5 \times 10^{-4} \mathrm{mmol}, 1\right.$ equiv. $)$ of naphthalimide monomer 6 were placed in a Schlenk tube and dissolved in $4 \mathrm{~cm}^{3}$ of absolute dichloromethane. After degassing, the polymerization was initiated with $1.15 \mathrm{mg}$ of modified second-generation Grubbs initiator $\mathrm{RuCl}_{2}\left(\mathrm{H}_{2}\right.$ IMes)(pyridine) ${ }_{2}(\mathrm{CHPh})$ (M31, $0.0016 \mathrm{mmol}, 1$ equiv.). TLC (cyclohexane/ethyl acetate 5/1, $\mathrm{KMnO}_{4}$ ) after $2 \mathrm{~h}$ proved full turnover. Subsequently, the polymerization was quenched with $200 \mathrm{~mm}^{3}$ of ethyl vinyl ether and stirred for $1 \mathrm{~h}$ at room temperature. Afterwards, the volume of the reaction mixture was reduced to $1 \mathrm{~cm}^{3}$ and the polymer was precipitated by dropwise addition of this solution to $200 \mathrm{~cm}^{3}$ of chilled, vigorously stirred methanol. After having repeated this process twice, the precipitated polymer was collected and dried in vacuo. Copolymerizations using monomers 7-10 and matrix monomers 12 and 13 were carried out analogously. Yields, GPC-data, and glass transition temperatures are summarized in Table 2.

Acknowledgements Open access funding provided by Graz University of Technology. This work is funded by the Austrian "Klima und Energiefonds" within the program Energy Emission Austria "PoTTA" (FFG: 841153). ACK acknowledges the Austrian Science Fund (FWF): T578-N19. The authors would like to thank Karin Bartl for MS-measurements and Kurt Stubenrauch for carrying out preliminary works on the synthesis of naphthalimide dyes.

Open Access This article is distributed under the terms of the Creative Commons Attribution 4.0 International License (http:// creativecommons.org/licenses/by/4.0/), which permits unrestricted use, distribution, and reproduction in any medium, provided you give appropriate credit to the original author(s) and the source, provide a link to the Creative Commons license, and indicate if changes were made.

\section{References}

1. Xiao P, Dumur F, Graff B, Gigmes D, Fouassier JP, Lalevée J (2014) Macromolecules 47:601

2. Liu J, Shao SY, Chen L, Xie ZY, Cheng YX, Geng YH, Wang LX, Jing XB, Wang FS (2007) Adv Mater 19:1859

3. Morgado J, Grüner J, Walcott SP, Yong TM, Cervini R, Moratti SC, Holmes AB, Friend RH (1998) Synth Met 95:113

4. Zhang J, Zhang X, Xiao H, Li G, Liu Y, Li C, Huang H, Chen X, Bo Z (2016) ACS Appl Mater Interfaces 8:5475

5. Wang Y, Zhang X, Han B, Peng J, Hou S, Huang Y, Sun H, Xie M, Lu Z (2010) Dyes Pigm 86:190

6. Srivastava AK, Singh A, Mishra L (2016) J Phys Chem A 120:4490

7. Cho DW, Cho DW (2014) New J Chem 38:2233 
8. Cao H, Chang V, Hernandez R, Heagy MD (2005) J Org Chem 70:4929

9. Jia X, Yang Y, Xu Y, Qian X (2014) Pure Appl Chem 86:1237

10. Tian H, Gan J, Chen K, He J, Song QL, Hou XY (2002) J Mater Chem 12:1262

11. Grabchev I, Yordanova S, Stoyanov S, Petkov I (2014) J Chem 2014:793721

12. Xu J-H, Hou Y-M, Ma Q-J, Wu X-F, Wei X-J (2013) Spectrochim Acta A 112:116

13. He C, Zhu W, Xu Y, Chen T, Qian X (2009) Anal Chim Acta 651:227

14. Guo X, Qian X, Jia L (2004) J Am Chem Soc 126:2272

15. Zhou J, Liu H, Jin B, Liu X, Fu H, Shangguan D (2013) J Mater Chem C 1:4427

16. Alaei P, Rouhani S, Gharanjig K, Ghasemi J (2012) Spectrochim Acta A 90:85

17. Trupp S, Schweitzer A, Mohr GJ (2006) Org Biomol Chem 4:2965

18. Kumar S, Koh J (2013) Carbohyd Polym 94:221

19. Yin H, Zhu W, Xu Y, Dai M, Qian X, Li Y, Liu J (2011) Eur J Med Chem 46:3030

20. Liang S, Yu H, Xiang J, Yang W, Chen X, Liu Y, Gao C, Yan G (2012) Spectrochim Acta A 97:359

21. Rouhani S, Nahavandifard F (2014) Sens Actuators B Chem 197:185
22. Wagner R, Wan W, Biyikal M, Benito-Peña E, Moreno-Bondi MC, Lazraq I, Rurack K, Sellergren B (2013) J Org Chem 78:1377

23. Li C, Hu Z, Aldred MP, Zhao L-X, Yan H, Zhang G-F, Huang Z-L, Li ADQ, Zhu M-Q (2014) Macromolecules 47:8594

24. Leitgeb A, Wappel J, Slugove C (2010) Polymer 51:2927

25. Hauser L, Knall A-C, Roth M, Trimmel G, Edler M, Griesser T, Kern W (2012) Monatsh Chem 143:1551

26. Hollauf M, Trimmel G, Knall A-C (2015) Monatsh Chem $146: 1063$

27. Gallas K, Knall A-C, Scheicher SR, Fast DE, Saf R, Slugove C (2014) Macromol Chem Phys 215:76

28. Bardajee GR, Li AY, Haley JC, Winnik MA (2008) Dyes Pigm 79:24

29. Breul AM, Hager MD, Schubert US (2013) Chem Soc Rev 42:5366

30. Gan J, Chen K, Chang C-P, Tian H (2003) Dyes Pigm 57:21

31. Gan J, Tian H, Wang Z, Chen K, Hill J, Lane PA, Rahn MD, Fox AM, Bradley DDC (2002) J Organomet Chem 645:168

32. Saha S, Samanta A (2002) J Phys Chem A 106:4763

33. Nandhikonda P, Paudel S, Heagy MD (2009) Tetrahedron 65:2173

34. Trupp S, Hoffmann P, Henkel T, Mohr GJ (2008) Org Biomol Chem 6:4319

35. Grabchev I, Konstantinova T (1997) Dyes Pigm 33:197 